\title{
DARI MIYANG KE LONGLENAN : PENGARUH JARINGAN SOSIAL PADA TRANSFORMASI MASYARAKAT NELAYAN
}

\section{Novi Dwi Harini ${ }^{凶}$}

SMA Muhammadiyah Tegal, Jawa Tengah, Indonesia

\section{Info Artikel}

Sejarah Artikel:

Diterima Juni 2012

Disetujui Juli 2012

Dipublikasikan September 2012

Keywords:

Longlenan;

Miyang;

Social networks;

Social transformation.

\begin{abstract}
Abstrak
Stereotip masyarakat miskin umumnya melakat bagi masyarakat wilayah pesisir pantai di Indonesia. Akan tetapi stereotip itu tidak berlaku bagi Masyarakat Desa Suradadi. Tingkat kesejahteraan masyarakat Desa Suradadi cukup tinggi. Hal ini sebabkan karena adanya proses transformasi masyarakat dari miyangan (nelayan tradisional) ke longlenan (nelayan moderen). Proses transformasi tersebut dipengaruhi oleh adanya peran serta jaringan sosial yang ada di masyarakat pesisir Desa Suradadi. Dalam penelitian ini penulis mengeksplorasi alasan yang melatar belakangi nelayan miyangan beralih ke longlenan, peran jaringan sosial terhadap akses kerja para calon nelayan longlenan, dan perubahan sosial yang terjadi di masyarakat. Penelitian ini menggunakan metode penelitian kualitatif. Subjek penelitian adalah nelayan (longlenan). Hasil penelitiannya adalah bahwa factor ekonomi, prestise, keinginan untuk melihat dunia luar merupakan dasar keputusan menjadi nelayan longlenan. Jaringan sosial yang digunakan nelayan longlenan adalah dengan berbagi informasi dan keberadaan broker. Dampak adanya nelayan longlenan adalah perubahan ekonomi, penghargaan sosial yang lebih tinggi terhadap profesi longlenan, perubahan gaya hidup, perubahan relasi dan nilai dalam keluarga, serta tranformasi profesi.
\end{abstract}

\begin{abstract}
Stereotypes as being impoverished are often attached to the inhabitants of coastal areas in Indonesia. But the stereotypes cannot be applied to the residents of Suradadi village where the villagers are quite prosperous. The economic advancement occurs in the village follows the transformation of fishing methods from miyangan (traditional fisherman) to longlenan (modern fisherman). The transformation is influenced by role of social networks that exist in the coastal village communities Suradadi. In this research, the author examines the roots of transformation from miyangan to longlenan, the role of social networks, and the social changes following the transformation in the community. The research use qualitative method. The study found that that the economic factor, prestige, a desire to see the outside world is the basis of transformation from miyangan to longlenan. To be longlenan, fishermen use social networks by sharing information and by being a broker. The impact of longlenan fishing is economic changes, higher social status of longlenan fishermen and the changes of lifestyle, family relationships and values.
\end{abstract}

(C) 2012 Universitas Negeri Semarang

\footnotetext{
Alamat korespondensi:

ISSN 2086-5465

SMA Muhammadiyah Tegal, Jawa Tengah, Indonesia 52461

E-mail: harini_novidwi@yahoo.com
} 


\section{PENDAHULUAN}

Sumber daya perikanan sebenarnya secara potensial dapat dimanfaatkan untuk meningkatkan taraf kehidupan dan kesejahteraan nelayan, namun pada kenyataannya masih cukup banyak nelayan yang masih hidup di bawah garis kemiskinan (Lindawati, 2007). Profesi sebagai nelayan merupakan salah satu profesi mayoritas masyarakat Indonesia selain profesi di bidang agraris (petani), yang merupakan hasil warisan turun-temurun. Kondisi mayoritas nelayan di Indonesia umumnya adalah nelayan tradisional dan miskin. Menurut Mubyarto (2004) nelayan miskin adalah jenis yang mendominasi kehidupan nelayan, di mana pendapatan dan perahu mereka tidak mencukupi kebutuhan hidupnya sehingga harus ditambah dengan pekerjaan lain untuk ia sendiri atau untuk istri juga anaknya.

Sejalan dengan apa yang disampaikan Mubyarto, Zid (2011) dalam penelitiannya mengemukakan bahwa keterlibatan seluruh anggota keluarga dalam mencari nafkah merupakan suatu upaya untuk bertahan hidup sekaligus respon keluarga terhadap kondisi kehidupan. Cara bertahan keluarga nelayan dalam meningkatkan kesejahteraan keluarga embededness adalah dengan melakukan adaptasi ekologi dan strategi nafkah (livelihood strategy). Zid menambahkan besar kecilnya pendapatan anggota keluarga akan mempengaruhi terhadap pola pengaturan konsumsi dan produksi keluarga nelayan. Temuan lain dalam penelitian Zid ini adalah peran ganda perempuan istri nelayan, pembagian kerja dan alokasi kerja suami istri, menabung, membeli perabut rumah, barang elektronik dan perhiasan mas pada realitasnya adalah cara yang dilakukan nelayan dalam melakukan strategi adaptasi ekologis (Zid, 2011).

Hal tersebut menimbulkan sebuah ironi. Bagaimana bisa, sebuah negeri dengan kekayaan laut yang begitu melimpah justru tidak memberikan kesejahteraan bagi para nelayan. Masyarakat nelayan yang mendiami pesisir lebih dari 22 persen dari seluruh penduduk Indonesia justru berada di bawah garis kemiskinan dan selama ini menjadi golongan yang paling terpinggirkan karena kebijakan dalam pembangunan yang lebih mengarah ke daratan. Menurut Razali (2004) kemiskinan selalu menjadi "trade mark" bagi nelayan dalam beberapa hal dapat dibenarkan dengan beberapa fakta seperti kondisi pemukiman yang kumuh, tingkat pendapatan dan pendidikan yang rendah, rentannya mereka terhadap perubahanperubahan sosial, politik, dan ekonomi yang melanda, dan ketidakberdayaan mereka terhadap intervensi pemodal, dan penguasa yang datang.

Menurut Kusnadi (2006a), secara faktual ada dua faktor yang menyebabkan kemiskinan pada masyarakat nelayan, yaitu faktor alamiah dan non alamiah (Abdurahman, dkk.2008). Menurut data Badan Pusat Statistik (BPS) tahun 2009, penduduk miskin di Indonesia mencapai 32,59 juta jiwa dan $63,47 \%$ di antaranya adalah masyarakat yang hidup di kawasan pesisir dan pedesaan. Firt mengemukakan bahwa masyarakat nelayan memiliki paling sedikit 5 karakteristik yang membedakan dengan petani pada umumnya, pertama pendapatan nelayan biasanya bersifat harian dan jumlahnya sulit ditentukan. Kedua, tingkat pendidikan nelayan maupun anak nelayan pada umumnya rendah. Ketiga, berkaitan dengan produk yang dihasilkan, ekonomi nelayan bersifat ekonomi tukar menukar. Keempat, bidang perikanan membutuhkan investasi yang besar dan cenderung beresiko. Kelima, kehidupan nelayan miskin diliputi kerentanan hidup (Haryono, 2005; Nasution 2008).

Kabupaten Tegal merupakan kota yang mempunyai daerah pantai yang luas yang terletak di sebelah laut utara pulau Jawa. Mayoritas masyarakat Kabupaten Tegal yang bertempat tinggal di daerah pinggiran pantai mempunyai profesi nelayan dan mereka pada posisi kesejahteraan yang cukup rendah ataupun miskin. Masyarakat nelayan merupakan manusia yang berkelompok begitu juga masyarakat nelayan yang ada di Desa Suradadi. Desa Suradadi yang notabenenya masyarakat nelayan, mereka memanfaatkan peran jaringan sosial dalam 
segala segi kehidupannya.

Relasi dan hubungan sosial itu terdapat diberbagai bidang kehidupan yang meliputi ekonomi, sosial, kebudayaan dan lain-lain yang mempengaruhi dalam perkembangan masyarakat Desa Suradadi itu tersebut. Umumnya seperti masyarakat yang lain, masyarakat nelayan di Desa Suradadi pasti selalu membutuhkan peran dari pihak lainnya. Namun, kesadaran mengenai pendidikannya yang masih tergolong rendah membuat warga Desa Suradadi enggan untuk menjajaki bangku pendidikan yang lebih tinggi. Hal ini mempengaruhi antar individu satu dengan individu yang lainnya sehingga warga Desa Suradadi tetap (stage) pada posisi Desa yang berpendidikan rendah, karena masyarakat Desa Suradadi menganggap pendidikan tinggi tidak menjamin untuk meningkatkan kehidupan mereka dan memperoleh pekerjaan yang layak.

Berbeda dengan masyarakat wilayah pesisir pantai di Indonesia yang pada umumnya mempunyai stereotip masyarakat miskin, namun nelayan-nelayan di Desa Suradadi tingkat kesejahteraanya cukup tinggi dibandingkan dengan daerah pesisir lainnya di Kabupaten Tegal. Hal ini disebabkan oleh adanya proses transformasi masyarakat dari miyangan (nelayan tradisional) ke longlenan (nelayan yang lebih maju dan global). Keadaan ini dipengaruhi oleh adanya peran serta jaringan sosial di masyarakat pesisir Desa Suradadi seperti yang telah dikemukakan di atas. Salah satu perkembangan yang terlihat dari Desa Suradadi adalah banyaknya bangunan rumah-rumah penduduk yang tergolong menengah ke atas.

Pada umumnya, keterbatasan masyarakat miskin terhadap mencari mata pencaharian yang layak juga dipengaruhi oleh faktor SDM yang rendah, baik dari faktor pendidikannya sendiri maupun keterampilannya (life skill), sehingga menyebabkan posisi tawar masyarakat miskin semakin lemah. Akan tetapi fenomena di Desa Suradadi menunjukkan hal yang berbeda. Banyak para nelayan Suradadi meskipun tidak memiliki pendidikan formal yang tinggi namun mereka mampu memperoleh pekerjaan yang layak.

Hal itu dapat terjadi karena banyak nelayan Suradadi yang menempuh jalur khusus yang mempermudah mereka untuk memasuki akses kerja walaupun tanpa mempunyai latar belakang pendidikan formal yang tinggi ataupun keterampilan khusus tertentu. Mereka dapat memperoleh pekerjaan dengan upah yang cukup besar dibanding dengan nelayan lokal tradisional atau "miyang", profesi itu masih berkaitan dengan laut, dan hasil laut. Hanya saja secara sistem dan pemaknaannya sudah berbeda, mereka tidak mau lagi disebut sebagai nelayan lokal atau tradisional, akan tetapi mereka menyebut dirinya sebagai pelayar (pelayaran) atau juga lebih dikenal di Desa Suradadi dengan sebutan "longlen" atau "longlenan".

Mereka yang semula bekerja sebagai nelayan lokal (miyang) yang mempunyai status rendah dan miskin, kini mereka bekerja sebagai tenaga kerja yang dalam pelaksanaan dan tempat kerjanya menginduk bersama perusahaan asing. Khususnya untuk angkatan usia muda mayoritas yang bekerja sebagai longlenan, mereka lebih merasa tertarik dengan profesi ini daripada harus meneruskan pekerjaan seperti orang tuanya yang hanya menjadi nelayan tradisional. Hal ini yang membuat para nelayan tersebut setidaknya naik satu tingkat lebih tinggi dari awal sebelum mereka berangkat berlayar (longlenan) dan di mata masyarakat mereka lebih mempunyai prestise (prestige).

Keinginan untuk menjadi pelayar di luar negeri (longlenan) dipengaruhi oleh keterlibatan jaringan sosial yang ada, dan menjadi semakin kuat setelah mengetahui keberhasilan yang diraih oleh kerabat, teman atau tetangga mereka yang sebelumnya menjadi nelayan kini bekerja di luar negeri. Penghasilan yang didapatkan setelah bekerja sebagai pelayar di luar negeri, terbukti mampu memenuhi baik kebutuhan hidup yang tidak hanya kebutuhan pokok saja melainkan juga kebutuhan sekunder.

Bekerja ke luar negeri tidaklah mudah, banyak persyaratan yang harus dipenuhi. Selain itu, proses yang harus dilalui juga tidak semudah yang dibayangkan. Secara tidak 
langsung, jaringan sosial merupakan salah satu faktor penentu dalam setiap kegiatan pelayaran yang berada di Indonesia. Selain faktor pendidikan, salah satu kendala yang sering dialami oleh para calon tenaga kerja pelayaran sehingga mereka menggunakan jasa jaringan sosial adalah: faktor usia, catatan kriminal, serta fisik dan kesehatan.

Pendidikan merupakan faktor pendukung yang dapat mempengaruhi jabatan para calon tenaga kerja. Melalui pendidikan, mereka dipat ditempatkan pada posisi-posisi sesuai dengan latar pendidikan dalam struktur pekerjaan. Nelayan yang memiliki latar belakang pendidikan yang rendah biasanya ditempatkan pada posisi pekerjaan yang rendah pula seperti sebagai ABK (Anak Buah Kapal) atau pekerja rendahan lainnya. Secara otomatis tingkat pendidikan menjadi penyaring pekerjaan dalam sistem nelayan yang tidak terelakan.

Sebagian besar dari warga Desa Suradadi yang ingin menjadi pelayar di luar negeri, tidak lepas dari keterlibatan jasa jaringan sosial, dalam hal ini yang dimaksud adalah teman, kerabat atau keluarga serta agen penyalur atau hal yang berkaitan dengan kemudahan dan kelancaran dalam hal proses bekerja di luar negeri. Khususnya jaringan sosial yang berupa agen penyalur terbentuk karena adanya permintaan. Jaringan sosial juga dapat berupa: petugas perusahaan itu sendiri, perekrut tenaga kerja atau sering disebut broker, oknum petugas dari instansi tertentu (perangkat Desa, TNI/ Polri, Imigrasi, dan lain-lain).

Kebanyakan dari para calon tenaga kerja pelayaran tersebut menggunakan jasa jaringan sosial (agen penyalur) karena mereka yakin dapat diterima walaupun dengan persyaratan pokok yang kurang sehingga banyak dari para pelaku jaringan sosial yang tidak bertanggung jawab memanfaatkan situasi yang seperti itu untuk mencari keuntungan pribadi, akan tetapi hal itu tidak menyurutkan langkah warga Desa Suradadi yang hendak bekerja/menjadi pelayar yang berlayar ke luar negeri. Dengan adanya kegiatan tersebut, membuat masyarakat di daerah pesisir menjadikan suatu kebiasaan yang berlangsung hingga sekarang tanpa adanya pihak-pihak yang merasa dirugikan.

Berdasarkan pada uraian di atas, penelitian difokuskan pada proses dari miyang ke longlenan sebagai studi jaringan sosial dan transformasi sosial masyarakat nelayan Desa Suradadi Kecamatan Suradadi Kabupaten Tegal. Secara rinci perumusan masalah adalah sebagai berikut: bagaimana alasan yang melatarbelakangi nelayan di Desa Suradadi lebih memilih berlayar ke luar negeri dibandingkan bertahan menjadi nelayan tradisional, bagaimana peran jaringan sosial terhadap akses kerja para nelayan di Desa Suradadi yang akan berlayar ke luar negeri, dan bagaimana perubahan sosial yang terjadi akibat terjadinya transformasi nelayan di Desa Suradadi.

Penelitian ini menggunakan tiga teori yaitu pertama, push factor theory dan pull factor theory teori ini menerangkan tentang profesi nelayan tetap menjadi pilihan terakhir masyarakat pesisir, salah satunya adalah, disebutkan bahwa profesi nelayan tetap menjadi pilihan terakhir dikarenakan tidak adanya peluang kerja di daratan (push factor theory). Selain itu, ada juga teori yang mengatakan bahwa profesi nelayan diminati karena menarik dan relatif menguntungkan (pull factor theory). Namun teori yang kedua ini tidak sesuai dengan kondisi masyarakat nelayan Indonesia yang tetap miskin.

Selain kedua teori tersebut, dipilihnya profesi nelayan dikarenakan bersifat given, di mana profesi nelayan menjadi the way of live yang diturunkan dari generasi ke generasi. Kedua teori jaringan, karena konsep jaringan dapat dipandang sebagai suatu proses kerjasama yang melalui media atau hubungan sosial yang berfungsi sebagai suatu sistem untuk mewujudkan tujuantujuan atau memenuhi kebutuhannya. Jaringan sosial merupakan suatu pola koneksi dalam hubungan individu, kelompok ataupun berbagai bentuk kolektif lain, yang mana hubungan ini bisa berupa hubungan interpersonal atau juga bisa bersifat ekonomi, politik atau hubungan sosial lainnya. Ketiga, teori perubahan sosial yang melihat dinamika dan perubahan sosial yang terjadi pada masyarakat akibat transformasi sosial.

Ahli antropologi harus dituntut untuk 
melihat interaksi dan pengaruh timbal-balik di antara kelompok-kelompok masyarakat yang berbeda-beda, karena hal ini dapat mengundang daya tarik sebagai objek kajian ilmiah. Perubahan-perubahan struktur masyarakatitumendorongdikembangkannya pendekatan-pendekatan baru dalam studi antropologi (Kusnadi,1998:10).

Analisis jaringan merupakan salah satu pendekatan dalam studi antropologi yang baru dikembangkan secara intensif pada tahun 70 -an. Pendekatan ini berkaitan dengan upaya memahami bentuk dan fungsi hubungan-hubungan sosial dalam masyarakat kompleks. Konsep jaringan sosial pertama kali diperkenalkan oleh Barnes (1954) pada saat dia meneliti masyarakat di Bremnes, Norwegia. Ketika mempelajari masyarakat tersebut, ia merasakan bahwa analisis struktural/fungsional pada masa itu (tahun 50-an) yang sudah umum digunakan oleh kalangan antropologi Inggris untuk meneliti suatu kebudayaan masyarakat dirasakan kurang mencukupi.

Sebelumnya studi-studi klasik di bidang antropologi telah memanfaatkan analisis struktural atau fungsional untuk memahami kebudayaan suatu masyarakat tribal atau masyarakat sederhana berskala kecil. Dengan analisis ini, ahli antropologi bisa mengungkapkan dengan baik keseluruhan aspek kebudayaan (holistik) dengan hubungan antar aspek kebudayaan masyarakat yang bersangkutan dalam kesatuan fungsional. Kesulitan yang dihadapi oleh Barnes adalah bahwa kondisi masyarakat di Bremnes yang tidak dapat lagi disebut masyarakat sederhana, sehingga ketika berupaya untuk memahami susunan hubungan-hubungan sosial yang terdapat di dalam masyarakat setempat, penerapan secara konvensional analisis struktural atau fungsional dirasakan kurang memadai lagi. Atas dasar itu, analisis jaringan sosial (social network) diusulkan untuk mengatasi kurang memadainya analisis structural atau fungsional (Mitchell, 1969:8).

Keterkaitan individu-individu dalam hubungan-hubungan sosial adalah pencerminan dirinya sebagai makhluk sosial. Dalam kehidupan masyarakat, hubungan-hubungan sosial yang dilakukan individu merupakan upaya untuk mempertahankan keberadaannya. Setiap individu memiliki kemampuan yang berbeda dalam hal kuantitas maupun kualitas atau intensitas hubungan-hubungan sosial yang dilakukannya, sekalipun dalam kehidupan masyarakat terbuka luas peluang bagi individu untuk melakukan hubungan sosial secara maksimal.

Hubungan-hubungan tersebut tidak hanya melibatkan dua individu, tetapi juga banyak individu. Keterhubungan antar individu-individu tersebut akan membentuk suatu jaringan sosial, yang sekaligus merefleksikan terjadinya pengelompokan sosial dalam kehidupan masyarakat. Pengertian jaringan tersebut mengacu pada hubungan-hubungan yang teratur, konsisten, dan berlangsung dalam jangka yang relatif lama.

Berkaitan dengan peran jaringan sosial memiliki peran bagi akses nelayan yang akan bekerja atau berlayan ke luar negeri yang ada di daerah pesisir Desa Surodadi, hal ini merupakan suatu penyelesaian permasalahan ekonomi dan peluang kerja yang terbatas yang ada di masyarakat nelayan yang cenderung miskin. Teori jaringan dalam perspektif sosiologi ekonomi adalah keterlekatan perilaku ekonomi dalam hubungan sosial dapat dijelaskan melalui jaringan sosial yang terjadi dalam kehidupan ekonomi, yang dapat dilihat bagaimana individu terkait antara satu dengan lainnya dan bagaimana ikatan afiliasi melayani baik sebagai pelicin untuk memperoleh sesuatu yang dikerjakan maupun sebagai perekat yang memberikan tatanan dan makna pada kehidupan sosial.

Tentang perubahan sosial, penelitian ini menggunakan konsep perubahan sosial dengan metodologi strukturis atau strukturasi yang melihat struktur sosial dan dan agency tidak bersifat dikotomis (seperti dalam pendekatan struktural), tetapi merupakan suatu simbolisme bagaikan ikan dan air yang satu dengan yang lain tidak bisa dipisahkan walaupun masing-masing memiliki wujudnya sendiri. Tujuan utama pendekatan strukturis ini adalah mencoba 
menentukan mengapa (faktor penyebab) suatu struktur sosial bertahan lama atau langgeng (reproduksi struktur sosial) (Leirizza, R.Z, 2004:5)

\section{METODE PENELITIAN}

Jenis penelitian yang digunakan dalam penelitian ini adalah penelitian kualitatif. Pemilihan metode kualitatif ini dimaksudkan agar dapat mempelajari, menerangkan atau menginterprestasikan suatu kasus dalam suatu masyarakat secara natural, apa adanya, dan tanpa adanya intervensi dari pihak luar.

Penelitian ini dilakukan dengan mengambil lokasi di wilayah Kabupaten Tegal lebih khususnya di Desa Suradadi Kecamatan Surodadi. Lokasi tersebut dipilih merupakan pusat kegiatan nelayan dan karena di sana banyak ditemukan orang-orang yang berbondong-bondong untuk berlayar ke luar negeri. Penelitian ini mendeskripsikan mengenai peranan jaringan sosial dalam kehidupan para warga pesisir pantai yang terletak di wilayah Kabupaten Tegal dalam hal ini adalah para nelayan lokal (miyang) yang kemudian berlayar ke luar negeri (longlenan).

Fokus penelitian ini adalah mendeskripsikan melalui pendekatan life history mengenai proses dari miyang ke longlenan sebagai studi jaringan sosial pada transformasi sosial masyarakat nelayan Desa Surodadi Kecamatan Surodadi Kabupaten Tegal. Penelitian ini difokuskan pada: alasan yang melatarbelakangi nelayan di Desa Surodadi lebih memilih berlayar ke luar negeri dibandingkan bertahan menjadi nelayan tradisional, peran jaringan sosial terhadap akses kerja para calon nelayan Desa Surodadi yang akan berlayar ke luar negeri, perubahan atau transformasi sosial yang terjadi pada masyarakat nelayan di Desa Surodadi setelah berlayar ke luar negeri.

Nelayan yang telah maupun yang akan bekerja ke luar negeri merupakan subjek penelitian ini. Informan dipakai untuk menambah kelengkapan data yang dibutuhkan seperti keluarga nelayan asal Desa Suradadi, para agen atau broker yang menyalurkan calon nelayan yang akan bekerja ke luar negeri, perangkat Desa Surodadi, aparatur negara yang mendukung penyaluran nelayan yang akan ke luar negeri seperti; polisi. Informan ini dapt memberikan kronologis dari fenomena proses transformasi nelayan miyang ke longlenan.

\section{HASIL DAN PEMBAHASAN}

Desa Suradadi terletak di daerah pantai utara (pantura) Kabupaten Tegal dan wilayahnya merupakan dataran rendah dengan ketinggian 0-15 meter di atas permukaan laut (dpl). Desa Suradadi juga bisa dikatakan sebagai pusatnya keramaian Kecamatan Suradadi, karena kantor Kecamatan, pasar Kecamatan Suradadi, dan puskesmas Suradadi berada di wilayah Desa Suradadi. Sekitar 50\% dari jumlah penduduk Desa Suradadi berprofesi sebagai nelayan yang terdiri dari nelayan tradisional atau lokal 25\% (usia 40-60 tahun) dan 75\% (usia 15-40 tahun) nelayan internasional atau pelayaran atau juga sering disebut warga Desa Suradadi dengan istilah "longlenan" yang terdiri dari kaum laki-laki, dan 20\% berprofesi sebagai PNS/TNI/POLRI serta selebihnya warga suradadi $30 \%$ berprofesi sebagai petani, pedagang, buruh pabrik, buruh bangunan, pengusaha dan lain-lain.

Tingkat pendidikan masyarakat Desa Suradadi yang rata-rata masih rendah. Tingkat pendidikan ini berpengaruh pada rendahnya tingkat ekonomi dan kondisi sosal masyarakat Suradadi. Tingkat pendidikan yang tinggi bagi para longlenan bukan merupakan penentu kesuksesan mereka ketika bekerja menjadi longlenan. Tingkat pendidikan para longlenan umumnya hanya tamatan SLTP. Bagi mereka hanya berbekal ijazah SLPT, mereka mampu menghasilkan pendapatan yang bisa dikatakan cukup dibanding dengan pekerjaan nelayan lainnya di Desa Suradadi.

Hal tersebut semakin menguatkan stigma bahwa jenjang pendidikan bukan penentu mendapatkan nasib/pekerjaan yang pasti. Kalaupun di masyarakat terdapat sejumlah anak yang mampu mengenyam pendidikan menengah hingga pendidikan tinggi, itu karena mereka adalah anak-anak 
orang yang mampu (orang tua PNS). Adikadik para longlenanpun dapat dikatakan sukses dalam hal pendidikan, sebab mereka mendapat bantuan dana pendidikan dari saudaranya yang bekerja menjadi longlenan.

Masyarakat Desa Suradadi merupakan masyarakat pesisir yang dalam varian regional budaya Jawa merupakan daerah pesisir utara bagian barat. Bentang sosial budaya masyarakat Desa Suradadi yang terletak di wilayah tersebut berpengaruh pada variasi keagamaan masyarakat di sana. Jalur pantai merupakan daerah yang bersifat terbuka, sebab daerah ini menjadi pintu gerbang untuk daerah lain di "pedalaman" Jawa. Dalam pandangan Geertz wilayah pesisir merupakan basis varian santri. Karena itu masyarakat di desa Suradadi mayoritas beragama Islam. Namun demikian dalam kehidupan sehari-hari pelaksanaan keagamaan masyarakat Desa Desa Suradadi tidak sepenuhnya bercirikan puritan sebagaimana identitas varian santri. Kondisi sosial budaya masyarakat Desa Suradadi masih dipengaruhi adat istiadat Jawa, dimana ada suatu seremonial sedekah laut, dan mereka sangat menjunjung tinggi kebersamaan dan gotong-royong.

Nelayan adalah profesi yang mayoritas ditekuni oleh masyarakat Desa Suradadi. Nelayan identik dengan profesi yang tidak memiliki prestis tinggi khususnya nelayan tradisional, akan tetapi menjadi nelayan adalah pilihan mayoritas warga pesisir pantai karena dengan berbagai keterbatasan baik pendididikan, biaya, dan keterampilan. Desa Suradadi mengenal konsep istilah lokal "miyang" yaitu nelayan tradisional yang mempunyai wilayah atau target pelayarannya di daerah lokal saja, dan mereka hanya menggunakan alat yang sederhana untuk menunjang pelayaran mereka seperti alat pancing yang kecil, jaring, perahu kecil, dan dalam proses pelayarannya untuk mencari hasil tangkapan laut pada setiap perahu terdiri minimal dua orang dan maksimal terdapat empat orang pada tiap pelayarannya.

Zaman dan kehidupan yang kian berubah dan global menuntut manusia untuk lebih terampil dan mengikuti perkembangan zaman agar mereka tetap bisa bertahan hidup terhadap gepuran perubahan yang dahsyat dan semakin moderen. Hal ini pulalah yang menyebabkan terjadinya transformasi sosial atau perubahan pada masyarakat nelayan khususnya fenomena yang terjadi di Desa Suradadi Kecamatan Suradadi Kabupaten Tegal yang beralih dari nelayan tradisional menjadi nelayan modern atau global. Lebih dari 50 \% masyarakat Desa Suradadi bermatapencaharian sebagai nelayan, umumnya pekerjaan yang mereka tekuni tersebut merupakan profesi turun-temurun yang diwariskan dari para pendahulunya.

Profesi turun temurun tersebut sampai saat ini masih ditekuni oleh sebagian masyarakat Desa Suradadi, akan tetapi karena pengaruh perubahan jaman sudah banyak bermunculan nelayan modern. Seperti yang sudah dijelaskan bahwa dengan adanya berbagai perubahan yang terjadi akhirnya banyak dari para nelayan tradisional (miyang) beralih profesi sebagai nelayan yang lebih modern atau global, dalam hal ini masyarakat Desa Suradadi sering menyebutnya dengan istilah "longlenan". Menurut keterangan dari bapak Tarsidjan selaku kepala Desa Suradadi, lebih dari setengah penduduk Desa Suradadi berprofesi sebagai nelayan, $75 \%$ diantaranya merupakan nelayan modern dan global (longlenan) yang berlayar sampai ke luar negeri, sedangkan $25 \%$ adalah sebagai nelayan tradisonal yang hanya berlayar di dalam negeri atau daerah lokal saja.

Berbagai teori telah menerangkan bahwa profesi nelayan tetap menjadi pilihan terakhir masyarakat pesisir, dikarenakan tidak adanya peluang kerja di daratan (push factor theory). Selain itu, ada juga teori yang mengatakan bahwa profesi nelayan diminati karena menarik dan relatif menguntungkan (pull factor theory). Namun teori yang kedua ini tidak sesuai dengan kondisi masyarakat nelayan Indonesia yang tetap miskin. Selain kedua teori tersebut, dipilihnya profesi nelayan dikarenakan bersifat given, di mana profesi nelayan menjadi the way of live yang diturunkan dari generasi ke generasi (Satria Tempo, 5 Juli 2003). Dengan demikian, banyak hal yang menyebabkan kenapa profesi nelayan menjadi pilihan terakhir. 
Namun yang pasti, profesi nelayan dari generasi ke generasi hanya mewariskan kemiskinan yang semakin akut karena kompleksnya permasalahan.

Dari hasil penelitian (observasi dan wawancara) di Desa Suradadi, kondisi sosialekonomi keluarga warga yang memutuskan berlayar ke luar negeri (longlenan) sebagian besar awalnya dapat dikategorikan sebagai keluarga miskin. Artinya dalam upaya pemenuhan kebutuhan primer, seperti kebutuhan makanan, pakaian, rumah yang sehat dan ideal, pendidikan, dan kesehatan masih dirasa berat, belum lagi ditambah dengan tuntutan keluarga akan pemenuhan kebutuhan sekunder, seperti membeli alat transportasi sepeda motor, perabotan rumah dan peralatan hiburan lainnya, serta memperbaiki kondisi rumah agar layak huni (Zid, 2011). Berdasarkan pada pengamatan maka ditemui tiga alasan sebagai berikut.

Konsep pokok yang disampaikan oleh Lippit diturunkan dari Lewin (1958) tentang perubahan sosial dalam mekanisme interaksional. Perubahan terjadi karena munculnya tekanan-tekanan terhadap kelompok, individu, atau organisasi. Ia berkesimpulan bahwa kekuatan tekanan (driving forces) akan berhadapan dengan penolakan (resistences) untuk berubah. Kehidupan sosial pada saat ini juga menuntut seseorang untuk mampu bertahan ditengah perkembangan jaman yang semakin global, hal ini menyebabkan para warga Desa Suradadi yang tergolong sebagai keluarga menengah ke bawah untuk mencari penghasilan yanglebihlayaksehingga mampu menyesuaikan dengan perkembangan dan kemajuan zaman. Penghasilan yang cukup besar mendorong warga Desa Suradadi lebih memilih untuk bekerja sebagai nelayan modern atau pelayaran (longlenan).

Dalam segi sosial ekonomi, warga Desa Suradadi khususnya yang bekerja sebagai nelayan modern atau pelayaran (longlenan) umumnya dijadikan sebagai tulang punggung keluarga karena dari hasil mereka bekerja dapat menghidupi seluruh keluarganya bahkan menyekolahkan adikadik mereka sampai jenjang yang lebih tinggi hal ini ditunjukkan dengan banyaknya warga Desa Suradadi yang berjenis kelamin perempuan justru memiliki pendidikan yang lebih tinggi dari pada warga Desa Suradadi yang berjenis kelamin laki-laki. Para pria itu lebih memilih mengutamakan pekerjaan daripada pendidikan karena menurut mereka pendidikan yang tinggi belum tentu menjamin kehidupan mereka dapat lebih baik dari sekarang.

Nelayan tradisional di era yang cukup maju sekarang ini, apalagi di mata anak muda di Desa Suradadi dirasa sudah sangat ketinggalan dan kurang menarik lagi bagi mereka. Longlenan selain sebagai jalan keluar dari permasalahan ekonomi yang lebih menjanjikan kesejahteraan, hal itu juga dianggap sebagi jalan keluar masalah sosial yaitu perubahan status di mana profesi longlenan dianggap mempunyai pengakuan dan prestise di masyarakat karena longlenan bukanlah dianggap layaknya nelayan tradisional yang dikenal penuh dengan keterbatasan sosial ekonomi tetapi longlenan dianggap lebih tinggi statusnya karena alat pendukungnya adalalah alat moderen dan lingkup pelayarannya lebih luas dan global walaupun dari segi kegiatan yang dilakukan dikapalpun sama yaitu sama-sama mencari ikan.

Berlayar, melihat dan singgah keluar negeri merupakan salah satu alasan seseorang untuk menjadi longlenan karena hal itu dirasa sangat menyenangkan, membanggakan dan mustahil dilakukan oleh orang yang tidak berpendidikan dan tidak memiliki banyak uang seperti layaknya profesi nelayan pada umumnya. Di sini dapat dilihat bahwa pull factor teori mempunyai pengaruh yang lebih besar dibanding push factor teori sebagai alasan masyarakat nelayan Desa Suradadi menjadi longlenan. Karena nelayan longlenan dirasa lebih bergengsi dan mempunyai pendapatan yang cukup besar serta dapat melihat dunia luar.

Fenomena transformasi yang terdapat di Desa Suradadi tidak mungkin lepas dari jaringan sosial yang ada di dalamnya. Fenomena profesi "longlenan " telah mengakibatkan transformasi sosial, ekonomi, dan budaya yang ada di masyarakat 
Desa Suradadi. Berawal dari penyebaran informasi antar warga Desa Suradadi, saling belajar dan berkeinginan meniru kesuksesan orang yang melakukan profesi menjadi longlenan, mengakibatkan daya tawar yang menarik dan merubah pola-pola kehidupan masyarakat Desa Suradadi yang ada sebelumnya dan yang membuat maraknya warga Desa Suradadi untuk berbondongbondang bekerja menjadi nelayan moderen cukup menggiurkan walaupun dengan bermodal pendidikan yang terhitung rendah. Menurut Salim (2008:156-157) dari perspektif jaringan, struktur sosial dikonsepsikan sebagai bentuk pertalian antara posisi-posisi atau simpul. Resiprositas ikatan akan menunjukkan adanya hubungan saling memiliki kepentingan di antara struktur jaringan yang telah terbentuk. Proses resiprositas menggambarkan adanya dua arah yang timbal balik antara poin satu dan poin yang lain. Dengan adanya hubungan timbal balik ini berarti intensitas hubungan telah terjadi dengan baik. Gambaran jaringan sosial yang di dalamnya terdapat aktor-aktor jaringan sosial yang berperan dalam proses perubahan atau transformasi masyarakat Desa Suradadi dapat dijelaskan dengan gambar berikut.

Ilustrasi gambar di bawah mendeskripsikan bahwa hubungan-hubungan yang digambarkan dengan arah panah yang saling timbal-balik antara aktor yang satu dengan aktor yang lainnya merupakan proses kerja jaringan sosial yang teraplikasikan ke dalam masyarakat Desa Suradadi, di mana proses tersebut membantu seorang subjek untuk menuju tujuannya menjadi seorang longlenan, dan yang dimaksud dengan subjek di sini adalah setiap warga Desa Suradadi yang akan dan telah menjadi longlenan dan jaringan sosial di sini bernilai karena bisa membantu seseorang untuk mencapai apa yang tidak dapat dicapainya sendirian.

Jaringan yang bernilai inilah yang kemudian membentuk pola koneksi dalam hubungan individu, kelompok ataupun berbagai bentuk kolektif lain. Pola koneksi itu membentuk hubungan interpersonal yang bersifat ekonomi, politik dan hubungan sosial lainnya. Hubungan-hubungan itu dimotori oleh sejumlah aktor-aktor yang berperan dalam memunculkan transformasi masyarakat nelayan Desa Suradadi. Aktoraktor tersebut antara lain broker, teman, tetangga, kerabat/keluarga, petugas instansi

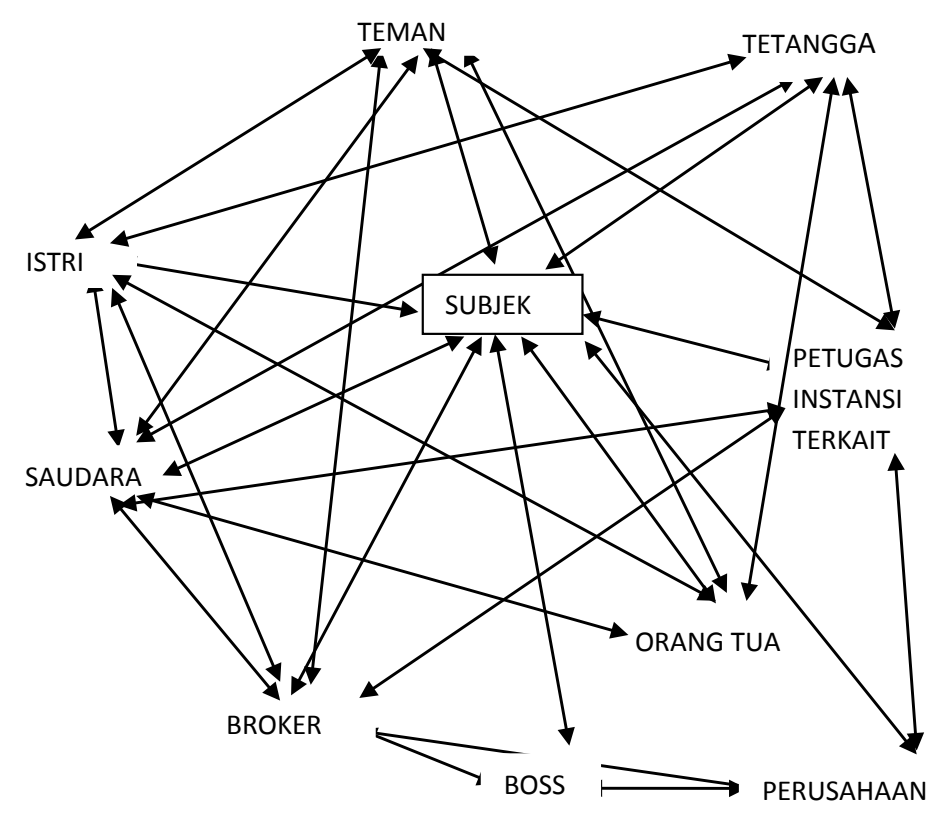

Gambar 1. Jaringan Sosial 
terkait. Mengacu pada pandangan Barnes (1954), aktor-aktor tersebut memainkan peranan yang berfungsi membentuk hubungan sosial dalam masyarakat nelayan Desa Suaradadi.

Saudara, orang tua, teman, dan tetangga adalah aktor yang sering mengetahui informasi lowongan menjadi longlenan dari berbagai sumber. Sementara broker, bos, pengusaha dan instansi yang terkait berperan dalam perantaan lebih lanjutan. Masingmasing menjalankan fungsinya dalam proses mengantarkan subjek menjadi longlenan seperti fungsi memberi informasi dan fungsi menyalurkan subjek hingga menjadi longlenan. Hal inilah yang dikatakan sebagai jaringan yang menjalankan keterhubungan antar aktor tersebut dalam rangka membentuk suatu jaringan sosial, dan dari situ menandai terwujudnya pengelompokan sosial dalam kehidupan masyarakat nelayan miyang ke longlenan.

Menurut Lippit dengan mengutip pandangan dari Lewin tentang perubahan sosial dalam mekanisme interaksional, perubahan terjadi karena munculnya tekanan-tekanan terhadap kelompok, individu, ataupun organisasi. Fenomena mengenai perubahan-perubahan dalam masyarakat Desa Suradadi dapat dianalisa dari berbagai segi diantaranya: ke "arah" mana perubahan dalam masyarakat itu "bergerak" (direction of change)", yang jelas adalah bahwa perubahan itu bergerak meninggalkan faktor yang diubah.

Ada tiga aspek masyarakat yang mengalami perubahan pada masyarakat Desa Suradadi yaitu perubahan dalam bentuk ekonomi, perubahan sosial, dan perubahan budaya. Akan tetapi perubahan itu bergerak kepada sesuatu bentuk yang baru sama sekali, akan tetapi boleh pula bergerak kepada suatu bentuk yang sudah ada di dalam waktu yang lampau baik bersifat positif ataupun cenderung bersifat negatif sesuai dengan nilai dan norma yang berlaku di dalam masyarakat Desa Suradadi dan dari ketiga aspek tersebut saling berkaitan dan berpengaruh.

Profesi longlenan yang sangat menjanjikan dalam segi penghasilan juga mempengaruhi taraf kesejahteraannya. Berkaitan dengan perubahan ekonomi masyarakat Desa Suradadi yang beralih menjadi longlenan dapat dilihat dari kondisi bangunan rumah, kendaraan, kepemilikan tanah, dan perubahan gaya hidup atau pola konsumsi (food, fashion, fun). Seorang longlenan biasanya mempunyai prioritas untuk mempergunakan pendapatannya dari berlayar ke luar negeri, yang utama digunakan untuk memperbaiki rumah, atau membeli rumah, kemudian membeli kendaraan yang bagus minimal sepeda motor, setelah itu mempersiapkan modal menikah atau menikah, dan yang terakhir mempersiapkan investasi untuk menunjang masa depan dengan cara membuka usaha lain seperti warung sembako, rental play station, bahkan membeli sawah.

Perubahan gaya hidup berubah seiring dengan meningkatnya ekonomi seseorang. Gaya hidup seseorang bisa dilihat dari pola konsumsi (food, fashion, fun) serta pola pergaulannya. Perubahan gaya hidup masyarakat nelayan yang menjadi longlenan yang pertama, dilihat dari segi jenis konsumsi yang meningkat seperti membeli alat hiburan, atau alat elektronik selalu mengikuti perkembangan yang ada. Selain itu dilihat dari segi penampilan baik longlenan itu sendiri maupun keluarganya juga otomatis berubah, seperti baju yang dikenakan lebih baik, selalu mengikuti mode yang sedang tren, dan selain emas dijadikan investasi emas juga digunakan sebagai barang penunjang aksesoris dan penampilan. Kedua, perubahan pola pergaulan seorang longlenan dipengaruhi oleh lingkungan kerjanya, Di sana mereka juga mendapatkan kehidupan dan pergaulan yang baru. Maka setelah mereka pulang dari berlayar, hasil pengadopsian pergaulan di mana saat dia bekerja secara sadar atau tidak sadar mereka terapkan dalam pergaulan di daerah asalnya.

Adanya penghargaan sosial yang mana seseorang yang mempunyai profesi longlenan mempunyai status yang lebih tinggi dibanding nelayan yang bukan longlenan karena dianggap seorang longlenan mampu meningkatkan taraf hidup keluarga, mapan dalam segi finansial, dan dianggap hebat 
karena mampu pergi ke luar negeri. Di sini pula muncul penghargaan sosial terhadap longlenan karena banyak orang tua yang mempunyai anak gadis, atau anak gadis itu sendiri bercita-cita dan merasa bangga apabila ia mendapatkan menantu atau suami seorang longlenan.

Di mata teman-teman dan tetangga, seorang longlenan yang sudah sukses juga biasanya dijadikan sebagai contoh dan motivasi untuk mencapai kesuksesan pula. Penghargaan sosial juga disandang oleh longlenan karena bisa mengangkat derajat keluarga, serta dapat menyekolahkan adikadiknya khususnya yang perempuan karena kebanyakan anak laki-laki di Desa Suradadi enggan melanjutkan sekolah hingga tingkat tinggi karena merasa pendidikan sampai tamat SMP sudah cukup untuk sukses menjadi longlenan. Sehingga banyak ditemukan fenomena perempuan di Desa Suradadi mempunyai jenjang pendidikan lebih tinggi minimal tamat SMA.

Profesi nelayan adalah profesi mayoritas masyarakat Desa Suradadi yang diturunkan secara turun temurun dari nenek moyang masyarakat Suradadi. Dukungan alam membuat mereka tetap bertahan dengan profesi tersebut. Adanya fenomena profesi longlenan secara langsung mempengaruhi berubahnya pula budaya masyarakat Desa Suradadi. Perubahan budaya yang terjadi, adalah tranformasi profesi/pekerjaan mayoritas masyarakat Desa Suradadi yang berawal dari nelayan tradisional kini berubah menjadi longlenan yaitu nelayan modern dan bersifat lebih global.

Perubahan profesi nelayan tradisional menjadi longlenan (nelayan modern) juga merubah peralatan hidup yang digunakan masyarakat Suradadi, misalnya saja dahulu para nelayan mencari tangkapan di laut hanya menggunakan pancingan kecil tradisional dan menggunakan jaring. Akan tetapi kini profesi longlenan yang merupakan perubahan bentuk dari nelayan tradisional mereka mencari tangkapan laut dengan kapal besar serta dilengkapi peralatan yang serba canggih yang digerakkan oleh robot-robot, hal tersebut juga membuat para longlenan menjadi ketergantungan dengan alat-alat yang serba praktis. Praktis merekapun sudah tidak begitu tertarik bahkan mulai merasa sulit apabila mereka pulang ke Desa mereka kemudian mereka disuruh menggunakan alat tradisional lagi. Dengan adanya mereka mengenal teknologi tersebut secara tidak langsung mereka memiliki pengetahuan yang meningkat

Profesi seorang longlenan menuntut dirinya untuk meninggalkan lingkungan asal dan keluarganya. Hampir semua longlenan adalah kaum pria, karena pada umumnya kaum wanita kurang bisa adaptif dengan situasi dan lingkungan pekerjaan kapal yang mempunyai resiko cukup tinggi dan keras. Pria yang sudah berstatus sebagai suami yang pula mempunyai profesi sebagai longlenan mau tidak mau harus meninggalkan istri dan anak hingga berbulan-bulan bahkan bertahun-tahun lamanya. Hal ini mendukung munculnya fenomena sosial di mana tingkat perceraian yang tinggi di Desa Suradadi dimana Desa Suradadi menduduki peringkat tertinggi angka tertinggi perceraian di wilayah Kabupaten Tegal. Dari data yang di peroleh dari Pengadilan Agama Kabupaten Tegal selama tiga tahun terakhir warga Suradadi yang mengajukan gugatan perceraian mendominasi angka perceraian di Kabupaten Tegal.

Perubahan sosial yang terjadi pada komunitas nelayan di Desa Suradadi akibat transformasi mereka dari miyangan ke longlenan dalam perspektif teori strukturasi tidak lepas dari peranan agency (para nelayan) yang memiliki potensi dalam mengubah diri dan nasib mereka untuk kehidupan yang lebih layak. Di samping itu, struktur sosial mereka juga memiliki peranan yang cukup signifikan dalam transformasi sosial mereka.

\section{SIMPULAN}

Masyarakat nelayan di Desa Suradadi memandang bahawa nelayan adalah sebagai the way of life. Hal tersebut terinternalisasi secara turunkan dari generasi ke generasi. Nelayan sebagai the way of life telah mengalami perubahan bentuk. Berkembangnya peradaban masyarakat saat ini mendorong masyarakat untuk 
mengikuti arus perkembangan global. Informasi dan jaringan yang telah terbentuk dalam lingkungan menjadikan nelayan Desa Suradadi melakukan transformasi dari miyang ke longlenan.

Berubahnya nelayan miyang (nelayan tradisional) menjadi longlenan (nelayan moderen) dengan kesuksesan yang menyertainya, mendgakibatkan munculnya fenomena masyarakat yang berbondongbondong menjadi longlenan. Alasan perubahan transformasi tersebut adalah dikarenakan adanya faktor utama yaitu ekonomi dan dari pengaruh peran jaringan sosial. Alasan ekonomi memang menjadi hal yang mendasar, namun adanya jaringan sosial menjadi hal yang tidak kalah penting. Sebab banyak masyarakat nelayan tetap bertahan dengan kemiskinannya karena tidak ada jaringan yang dibangun dalam proses melakukan transformasi sosial yang lebih baik.

Peran jaringan sosial terhadap akses kerja para nelayan di Desa Suradadi yang akan berlayar ke luar negeri sangat berpengaruh, yaitu dengan cara berbagi informasi dan saling mempengaruhi satu dengan yang lainnya. Aktor yang paling menonjol serta berpengaruh dalam memunculkan fenomena perubahan dari miyangan ke longlenan adalah broker. Peranan brokerlah yang mempermudah akses seseorang menjadi longlenan dengan penghasilan yang cukup menggiurkan.

Perubahan sosial yang terjadi akibat transformasi nelayan di Desa Suradadi adalah petama, adanya perubahan ekonomi. Perubahan ekonomi tersebut juga berpengaruh pada meningkatnya tingkat pendidikan di Desa Suradadi. Akan tetapi peningkatan pendidikan ini terjadi pada kaum perempuan baik adik maupun kakak dari pelaku longlenan. Pada kasus ini kaum pria lebih mengutamakan menjadi longlenan dari pada peningkatan pendidikannya. Kedua, perubahan gaya hidup yang dialami oleh keluarga nelayan tradisional. Gaya hidup keluarga yang menjadi longlenan dapat dilihat dari pola konsumsi (food, fashion, fun) yang meningkat, serta pola pergaulan yang diadopsi dari lingkungan longlenan saat berlayar di luar negeri.

Ketiga, penghargaan sosial yang diperoleh oleh seorang longlenan dan keluarganya. Prestis sosial yang disandang oleh para longlenan dan keluarga dianggap jauh lebih tinggi dari pada nelayan tradisional. Keempat, munculnya perubahan profesi nelayan. Perubahan profesi ini berupa transformasi nelayan tradisional (miyang) menjadi nelayan moderen (longlenan). Perubahan profesi juga ditandai oleh jenis peralatan yang digunakan nelayan yang cenderung menggunakan teknologi moderen. Terakhir, adalah perubahan relasi sosial dimana terdapat fenomena tingginya angka perselingkuhan dan perceraian di Desa Suradadi.

Saran dari hasil penelitian ini untuk: (1) pemerintahan Desa Suradadi diharapkan dapat berkomunikasi secara efektif dengan broker agar nantinya dapat menfasilitasi secara baik terhadap para calon longlenan. (2) warga masyarakat yang hendak menjadi pekerja longlenan apabila menggunakan jasa seorang broker supaya lebih selektif dalam memilih seorang broker dan menambah keterampilan sebagai penunjang pekerjaanya. Agar tidak merasa dirugikan oleh broker yang tidak bertanggung jawab. (3) keluarga longlenan yang menghadapi masalah perselingkuhan dan perceraian perlu adanya komunikasi yang cukup baik antara pihak suami dan istri yang bertujuan untuk mengurangi resiko hubungan jarak jauh.

\section{DAFTAR PUSTAKA}

Abdurahman, A., Arifin, S. dan Harjito, D.A. 2008. Model Kebijakan Pemberdayaan Nelayan Bantul Ditinjau dari Perspektif Ekonomi dan Hukum. Jurnal Fenomena. 6(1): 1-19

Haryono, T.J.S. 2005. Strategi Kelangsuhan Hidup Nelayan Studi tentang DiversifikasiPekerjaan Keluarga Nelayan Sebagai Salah Satu Strategi dalam Mempertahankan Kelangsungan hidup. Jurnal Berkala Ilmiah Kependudukan. 7(2): 119128

Husain, F. 2011. Sistem Budaya Bahari Komunitas Nelayan Lungkak Desa Tanjung Luar, Lombok Timur, Nusa Tenggara Barat. Jurnal Komunitas. 3(1): 40-50.

Kusnadi. 1998. Jaringan Sosial Sebagai Strategi Adaptasi Masyarakat Nelayan (studi kasus 
di desa Pesisir kecamatan Besuki kabupaten Situbondo JATIM. Tesis Pusat Pengembangan Penelitian Ilmu-ilmu Sosial UI.

Leirizza, R.Z, 2004. Charles Tilly dan Studi tentang Revolusi Sosial. Jurnal Sejarah. 6 (1): 55-79.

Lindawati. 2007. Faktort-faktor yang Mempengaruhi Peluang Berusaha dan Kegiatan Ekonomi Rumah tanggaIstri Nelayan Pekerjadi Kecamatan Medan Belawan. Jurnal Perencanaan dan Pengembangan Wilayah. 3 (1): 1-8.

Moleong, L. 2006. Metode Penelitian Kualitatif. Bandung: PT. Remaja Rosdakarya

Mitchell, J.C. 1969. The Concept and Social Network. Manchester: Manchester University Press, hal. $1-50$

Nasution, Z. 2008. Perkembagan Ekonomi Masyarakat Nelayan Perairan Umum "Lebak Lebung. Jurnal Transdisiplin Sosiologi, Komunikasi dan

\section{Ekologi Manusia. 2(2): 249-264}

Razali, I. 2004. Strategi Pemberdayaan Masyarakat Pesisir dan Laut. Jurnal Pemberdayaan Komunitas. 3(2): 61-68

Ritzer, G dan Goodman, D. J. 2010. Teori Sosiologi Cetakan: kelima. Bantul: Kreasi Wacana Offset

Salim, A. 2008. Pengantar Sosiologi Mikro. Yogyakarta : Pustaka Pelajar

Siagian, M. 2004. Kondisi Sosial Ekonomi dan Partisispasi Ekonomi Isteri Keluarga Nelayan. Jurnal Pemberdayaan Komunitas. 3(2): 112-118

Soekanto, S. 2006. "Sosiologi Suatu Pengantar". Jakarta: PT. Raja Grafindo Persada

Zid, M. 2011. Fenomena Strategi Nafkah Keluarga Nelayan: adaptasi Ekologis di CikahuripanCisolok Sukabumi. Jurnal Sosialitas. 9 (1): 3238. 